\title{
Editorial
}

\section{Decolonizing rights: strategies and directions}

This edition of the Journal of Human Rights and the Environment foregrounds strategies and directions for the decolonization of rights discourse and resistance to modes of extractivist plunder and eco-violation. In various ways, the authors identify resistive approaches to the broadly neo/colonial imperatives of the extractivist global order and its savage fallouts. A range of approaches are identified: the Latin American shifting of constitutional paradigms in moves towards legal personhood for natural systems and entities; grassroots Latin American deployments of pluriversal biocultural rights; Canadian activist degrowth strategies; global social movement protests against climate vandalism; the reframing of European Union (EU) environmental protection by deploying Hohfeldian correlativity to identify rights-based eco-protection emerging despite the current limits of EU jurisprudential ontology.

Together, the imaginative, ground-breaking approaches discussed by the authors in this edition offer insights that converge - in broad terms - around the decolonization either explicitly or implicitly - of rights-based approaches and/or their underlying onto-epistemology. Human rights, set against the extensive eco-violence of the neoliberal international order, are challenged by this edition to reconfigure their discursive limits, while the imaginative potency of biocultural rights and the resistive potentiality of rights of nature are brought to bear. Supporting such moves, and convergent with their resistive direction, are social movement activisms, Indigenous political ontologies, and the prefigurative economic strategies of the degrowth movement.

While this editorial cannot do justice to the rich themes and strands emerging in the edition, it is possible to detect a central underlying problematic pivotal for the concerns of the articles. This problematic is the dominance of (and violence enacted by) the multiformed 'extractivism' that Saskia Sassen has characterized as the central feature of the expulsive (and expanding) 'operational space of advanced capitalism'. ${ }^{1}$

Latin America is a space especially marked by intense struggles against such brutal extractivism. In 'Legal personhood of Latin American rivers: time to shift constitutional paradigms?', Amaya Álvez-Marín, Camila Bañales-Seguel, Rodrigo Castillo, Claudia Acuña-Molina and Pablo Torres offer an analysis of three Latin American legal paradigms that address the entanglement of humans and 'nature'. The authors, drawing three Latin American constitutional orders into a comparative critical analysis, deploy rivers as 'emblematic' elements of nature that currently press the imaginary of legal personhood in new directions. The authors identify some challenges and opportunities generated by the emergent legal paradigm of 'New Latin American Constitutionalism', arguing that it directly challenges liberal law's generic Eurocentrism. This New Latin American Constitutionalism expressly draws the knowledges

1. S Sassen, 'A Savage Sorting of Winners and Losers: Contemporary Versions of Primitive Accumulation' (2010) 7/1-2 Globalizations 23-50; S Sassen, 'At the Systemic Edge: Expulsions' (2016) 24/1 European Review 89-104. 
and worldviews of Indigenous peoples into the national constitutional regulation of Nature - a shift the full realization of which necessarily demands 'a profound review of the extractivist economic model and the capitalist logic that supports it'. While Chile emerges from the authors' analysis as being largely captive to the imperatives of advanced capitalism's extractivist logics, Colombia makes highly visible the lack of adequate protection for rivers, while Ecuador provides resistive promise: 'its model runs contrary to the dominant economic mode'. For the authors, the paradigm of the rights of Nature allows for an alternative perspective through which to view environmental crisis - and, at least in the Latin American constitutional orders under analysis, presupposes the 'active consideration of local and Indigenous knowledge and norms, which are rooted, and have evolved, in their specific geographical space'. Such situated normativities, argue the authors, are directly reflected in recognition of the legal personhood of rivers, while biocultural rights should be understood to be inherently situated, relational and epistemically open to multiple knowledges (including science).

In 'Posthuman rights struggles and environmentalisms from below in the political ontologies of Ecuador and Colombia', Rosemary J Coombe and David J Jefferson examine the dynamic energies of the political ontologies and 'posthuman legalities' at work in Latin America, specifically in Andean Community countries. Coombe and Jefferson unfold the way in which natural and cultural forces are 'inextricably interrelated under the principle of the pluriverse' and, like Álvez-Marín et al., highlight the constitutional changes in the region that have affirmed plurinationality and interculturality in response to Indigenous struggles and wider social movement efforts. The authors offer a beautifully drawn, rich and sensitive ethnographic account of the ways in which Indigenous, Afro-descendent and campesino communities express, through the concept of buen vivir, 'multispecies relations of care and conviviality'. These multispecies relations are lived in explicit opposition to extractivist development, and collective Andean modes of living generate a distinctive praxis of rights 'from below' 'to support new practices of territorialization that further materialize nature's rights and community ideals'. The 'posthuman legalities' expressed in the 'unique couplings of collective action and litigation for collective rights' deployed by Andean communities and activists, the authors argue, support the broader decolonization of human rights: 'Rights activism in Ecuador and Colombia has elevated new political ontologies and legitimated grounded responsibilities in materializing multispecies territorial jurisdictions'. The appropriation and rearticulation of rights has been central to such attempts to actualize community collective life projects - and in the process of articulating (and implementing) third generation rights through a biocultural paradigm, nature's rights are affirmed, while legal recognition of alternative normativities 'exceed[s] modern ontologies'.

Latin America is a site of profound political and legal creativity in response to the pervasive extractivism characterizing the advanced capitalism. Such logic is brutally enacted, after all, against Indigenous and other communities and the more-thanhuman liveliness of Latin America. Meanwhile, resistance to such logics is also taking shape in other regions, jurisdictions and strategies.

One strategy, adopted by Yaffa Epstein and Hendrik Schoukens in 'A positive approach to rights of nature in the European Union' is to press European Union (EU) legal ontology beyond its traditional limits by deploying positivist jurisprudential logic. Epstein and Schoukens concede that while a growing number of jurisdictions have recognized rights of nature, Europe has not thus far been a noticeable part of this important shift. Nevertheless, argue the authors, the apparent absence of rights of nature in EU law is misleading, because nature is protected by state duties imposed 
by European environmental protection laws, meaning that nature has rights on the basis of Hohfeldian correlativity. To support their Hohfeldian argument, Epstein and Schoukens analyse recent decisions of the Court of Justice of the EU concerning, in particular, the protection of wolves. Nature (read through the correlativity argument applied to wolves) already enjoys 'some legal rights that cannot be trumped by mere utilitarian interests'. Such rights, moreover, can already be recognized and interpreted by national courts drawing on EU law, regulation and jurisprudence. The authors construct a supporting argument based on rights of standing granted under EU law to environmental NGOs, rights that enable public interest litigation to deploy the language of rights for nature notwithstanding the lack of 'explicit' recognition of such rights in EU law or in national legislation. The authors argue that not only does nature (as protected by EU law) have Hohfeldian legal rights correlative to the state's protective duties, but parallels can also be drawn with fundamental human rights, and that while these rights have not yet explicitly been recognized, they are discernible in the judicial weight given to the eco-protective implications of EU environmental measures. For Epstein and Schoukens such rights are also implied by the rights of standing granted to NGOs and others in the form of procedural environmental rights designed to allow public interest litigants to seek enforcement of EU environmental law. Accordingly, the convergent normative effect of Hohfeldian correlativity; the link between procedural rights and underlying duties to protect the environment and the recognition of the intrinsic value of biodiversity in the EU legal order all add up - in effect - to the recognition (no matter how currently understated) of rights of nature in EU law. Courts therefore have the opportunity, the authors conclude, explicitly to recognize such rights.

Rights of standing for environmental NGOs is in one sense an operational recognition of law's need to allow humans to 'speak for' nature. Speaking for nature, and for the rights of future generations, is a central concern in the article by Manuela Niehaus and Kirsten Davies: 'Voices for the voiceless: climate protection from the streets to the courts'. Niehaus and Davies, in reflecting on such representational praxis, focus on how 'social movements and climate litigation activisms can influence and foster stronger climate policies' and explore where the current wave of climate strikes and other forms activism might lead law. In particular, the authors wonder whether such upsurges in social energy and consciousness-raising can reach out to embrace the 'voiceless': future generations and nature. Niehaus and Davies read the climate strikes as 'rights-based' community uprisings sharing much with past social activisms around anti-nuclear protests and in support of women's rights. The common thread that the authors highlight is the insight that international collective action 'holds the power to create legal change'. The authors argue that courts are emerging as central to the empowerment of resistive social movements in 'contemporary global environmental governance' by imaginatively developing domestic and international law in order to respond to new urgencies. Litigation has thus become an activist strategy and 'courts are becoming the guardians both of people and the environment'. The rights of nature, in this context, form a particularly powerful adjunct to human rights, which remain limited, in central respects, by their inherent anthropocentrism. Social movements, activisms and struggles still have a centrally important role in liberating human rights discourse from its ontological limits and they operate as powerful ways of putting pressure on governments.

Taking the urgency of the climate crisis as a stepping off point with the words of Greta Thunberg ('We are in the beginning of a mass extinction, and all you can talk about is money and fairy tales of eternal economic growth. How dare you!'), Claire O'Manique, James K Rowe and Karena Shaw analyse the limitations placed on the degrowth agenda, characterizing the agenda as an attempt at wide-scale transformation 
of the global economic system in line with planetary limits. In 'Degrowth, political acceptability and the Green New Deal', the authors start from the central degrowth premise: the impossibility of endless economic growth on a finite planet. Noting the power of this premise, the authors address the question of why, despite the compelling nature of its logic, the degrowth movement has struggled to gain political acceptability and traction. O'Manique et al. unfold their reflections on this question based on interviews with Canadian degrowth activists. The interviews reveal a centrally problematic barrier to the realization of degrowth goals: the 'concentrations of elite and corporate power' that give such actors 'immense political, economic and cultural power'. This 'class power' is mobilized against effective climate action and is also a barrier to the political plausibility of the degrowth agenda. In response to this central challenge - which is readable as yet another dimension of the deepening grip of advanced expulsive capitalism's relentless extractivism - activists interviewed by the authors highlighted the need to develop a class-conscious environmentalism, an 'anti-purity' politics, and overt decolonization as core strategic elements of the degrowth agenda. Finally, the authors analyse the Green New Deal (GND) as a promising 'non-reformist reform' for the degrowth movement to pursue. The authors conclude that the GND, which rose to prominence after they had conducted their interviews, presents a possible route by which to combine class-conscious environmentalism, anti-purity politics and decolonial imperatives in one strategic programme. GND's appeal to multi-racial working-class people (it prioritizes job creation), the authors suggest, might help to inoculate GND politics against fossil capitalist class interests - thus holding out hope of progress. And, while the GND is far from 'pure', the authors note that Indigenous activists and anti-colonial settlers within the GND movement are moving it into decolonial directions. Accordingly, the GND creates the possibility of meaningful political resistance to neoliberal imperatives.

Whether or not - and the degree to which - the pervasive extractivism destroying human and more-than-human lives, beings and systems the world over can ultimately successfully be addressed by the strategies discussed in this edition, it is clear that these strategies are energetic signs and modes of active, prefigurative solution-seeking. The authors signal to the reader that there are hopeful signals of nascent shifts and developments moving law, politics and economics in a more life-generative direction, but also that there is clearly so much to struggle for (and against).

There is such a profound need for scholars, practitioners, activists, communities and others to continue to reach for alternative ways of co-living, and to do so in imaginative, daring and paradigm-exceeding ways.

Anna Grear

Editor in Chief, Professor of Law and Theory, Cardiff Law School 